\title{
CLASSIFICATION OF CUSTOMER COMPLAINTS ON INSTAGRAM COMMENTS USING NAÏVE BAYES ALGORITHM WITH N-GRAM FEATURE EXTENSION
}

\author{
Fachri Amsury; Nanang Ruhyana; Irwansyah Saputra; Daning Nursulistyowati \\ Program Studi Sistem Informasi \\ STMIK Nusa Mandiri, Jakarta, Indonesia \\ www.nusamandiri.ac.id \\ fachri.fcy@nusamandiri.ac.id, nanang.ngy@nusamandiri.ac.id,irwansyah.iys@nusamandiri.ac.id, \\ daning.dgs@nusamandiri.ac.id
}

\begin{abstract}
Customer complaints about the company can be used as a form of self-evaluation and performance that has been carried out by the company, based on customer complaints the company can find out the weaknesses that exist in the company and fix them. The forms of submitting customer complaints are very diverse, currently not only by telephone, but customers also submit suggestions or complaints, customers can submit suggestions or complaints via electronic mail or $e$ mail or forums in cyberspace that are indeed created by product-producing companies to accommodate various complaints, suggestions, and direct criticism from consumers, especially social media that are free to express opinions on the delivery services used. Instagram is a social media that is more inclined towards images and on the other hand, has captions and comments text, a study is needed for the problem of customer complaints from shipping service users on an Instagram account of a delivery service company. Based on this background, a solution is needed in solving problems for text mining classification using Naïve Bayes with SMOTE techniques and $\mathrm{N}$-Gram feature extraction with the usual process for text mining so that it can produce Naïve Bayes and SMOTE accuracy with an accuracy of $88.54 \%$, before implementation. $N$-Gram and the accuracy rate increased by $1.44 \%$ after the $N$-Gram Term was applied to $89.98 \%$ by using a dataset of 776 Instagram comment text records that had to preprocess text.
\end{abstract}

Keywords: Classification, Comments Instagram, Complaints, Naïve Bayes, SMOTE Technique, NGram.

Intisari- Keluhan pelanggan bagi perusahaan dapat dijadikan sebagai bentuk evaluasi diri dan kinerja yang telah dilakukan oleh perusahaan, berdasarkan keluhan pelanggan perusahaan dapat mengetahui kelemahan yang ada pada perusahaan dan memperbaikinya. Bentuk penyampaian keluhan pelanggan sangat beragam, saat ini tak hanya melalui telepon saja pelanggan menyampaikan saran atau keluhannya, pelanggan bisa menyampaikan saran atau keluhannya melalui surat elektronik atau e-mail maupun forum-forum di dunia maya yang memang dibuat perusahaan penghasil produk untuk menampung beragam keluhan, saran, dan kritik langsung dari konsumen terlebih sosial media yang bebas mengutarakan pendapat terhadap jasa pengiriman yang digunakan. Instagram merupakan sebuah sosial media yang lebih cenderung kepada gambar dan disisi lain mempunyai teks caption dan komentar, dibutuhkan sebuah penelitian untuk permasalahan keluhan pelanggan pengguna jasa pengiriman barang pada sebuah akun Instagram perusahaan jasa pengiriman. Berdasarkan latar belakang tersebut dibutuhkan sebuah solusi dalam memecahkan masalah untuk klasifikasi text mining dengan menggunakan Naïve Bayes dengan teknik SMOTE dan ekstraksi fitur $\mathrm{N}$-Gram dengan proses yang biasa dilakukan untuk text mining sehingga dapat menghasilkan akurasi Naïve Bayes dan SMOTE dengan akurasi $88.54 \%$, sebelum diterapkan $N$-Gram dan tingkat akurasi meningkat sebanyak 1.44\% setelah diterapkan N-Gram Term menjadi 89.98\% dengan menggunakan dataset teks komentar Instagram sebanyak 776 record yang sudah dilakukan teks preprocessing.

Kata Kunci: Klasifikasi, Komentar Instagram, Keluhan, Nä̈ve Bayes, Teknik SMOTE, N-Gram

\section{INTRODUCTION}

Indonesia has a variety of social media users, both men and women ranging from children, adolescents, adults, and the elderly. APJII takes a picture of the number of internet users in Indonesia, the result is that internet users in Indonesia have increased by $10.12 \%$ in 2018 compared to the previous year. The total number of internet users reached 171.17 million out of a population of 264.16 million (APJII, 2019). Meanwhile, around $75.47 \%$ of companies use 
Instagram social media (Sabirin \& Setiawati, 2017). Every company to survive and compete with its competitors needs a new sales strategy, one of the company's activities is to sell a product for profit, to achieve the target a company is required to be able to promote and market products that are sold quickly but not many resources are wasted (Hartini, 2016).

Customer satisfaction is one of the things that a company expects when the resulting product has been marketed, either in the form of goods or services. Coupled with tough competition (Mayasari \& Indriyani, 2016) between companies that produce similar products make companies compete to produce products according to consumer desires. However, it is not always the product that reaches the customer that it is completely free from problems (Putri, 2016), With the development of buying and selling online through various media, both purchasing via ecommerce sites or through social media is very easy, according to (Widagdo, 2016) the development of e-commerce is very interesting to discuss because over time, the telecommunications industry will develop both in terms of service coverage and internet connection speed. Payment system support that becomes easy, then electronic transactions or e-commerce activities will grow.

An increasing number of complaints given by customers require extra attention for every company that receives complaints to improve in manufacturing (Susi Indriyani, 2014) products or services (S. Indriyani \& Mardiana, 2016). Often customers find problems in the use of products, either due to production errors or misuse of ways other than the delivery of goods, which are relatively more frequent problems experienced by customers, so that customer trust in goods delivery services is also very influential because the products purchased by consumers are expected quickly reach the customer.

Customer complaints can be submitted in various ways, for example through customer service, the use of technology allows increased effectiveness in service recovery, social media has been widely used by companies like customer service (Setiawan \& Setyohadi, 2017). Customers can submit suggestions or complaints via electronic mail, e-mail, or forums on the internet created by product selling companies to accommodate various complaints, suggestions, and criticism directly from customers, especially on social media that are free to express their opinions on their delivery services wear. After going through this step, the company represented by customer service collects and analyzes complaints from customers to take action on the next step, which is of course by customer requests (Dewi, 2018).

Several studies have been conducted on customer complaints using the following classification research conducted by Prieta Dellia and Aris Tjahyanto regarding the classification of tax complaints on Twitter in 2017(Dellia \& Tjahyanto, 2017). Other research on twitter classification text for complaints of Bandung city government (Laksana \& Purwarianti, 2015). The next research is the classification of Instagram comments to identify customer complaints of goods delivery services using the SMOTE technique (Ruhyana \& Rosiyadi, 2019). Based on previous research, this study aims to use text mining to classify customer complaints on Instagram social media by taking text comments on one of the Instagram accounts of goods delivery services using the Naive Bayes method, adding SMOTE techniques and $\mathrm{N}$-Gram feature extraction to increase accuracy so that it can make comparisons between the accuracy using the N-Gram feature and not using the $\mathrm{N}$-Gram feature.

This study tries to improve the accuracy of the classification of customer complaint data on Instagram comments by using the Naïve Bayes algorithm using the SMOTE technique by adding the N-Gram feature to predict comments that contain complaints and not complaints. Then look at the level of accuracy of the method used before and after the application of the N-Gram term feature. The data from this research can be used for companies to reconsider their policies for decision making.

\section{MATERIALS AND METHODS}

The research methodology used in this study is the Cross-Standard Industry for Data Mining (CRISP-DM) method, the CRISP-DM research method consists of 6 steps (Sieber, 2008) Business Understanding, Data Understanding, Data Preparation, Modeling, Evaluation, Deployment.

Based on Figure 1, this research model discusses the classification of customer complaints about delivery services based on Instagram comments using the Naïve Bayes algorithm with the SMOTE technique and the N-Gram feature. The data is taken from the Instagram comment of the @jne_id service account, the data used is 776 records with two attributes, namely text, and status, then labeling each comment with the complaint label is 554 records and 222, not complaint records. 


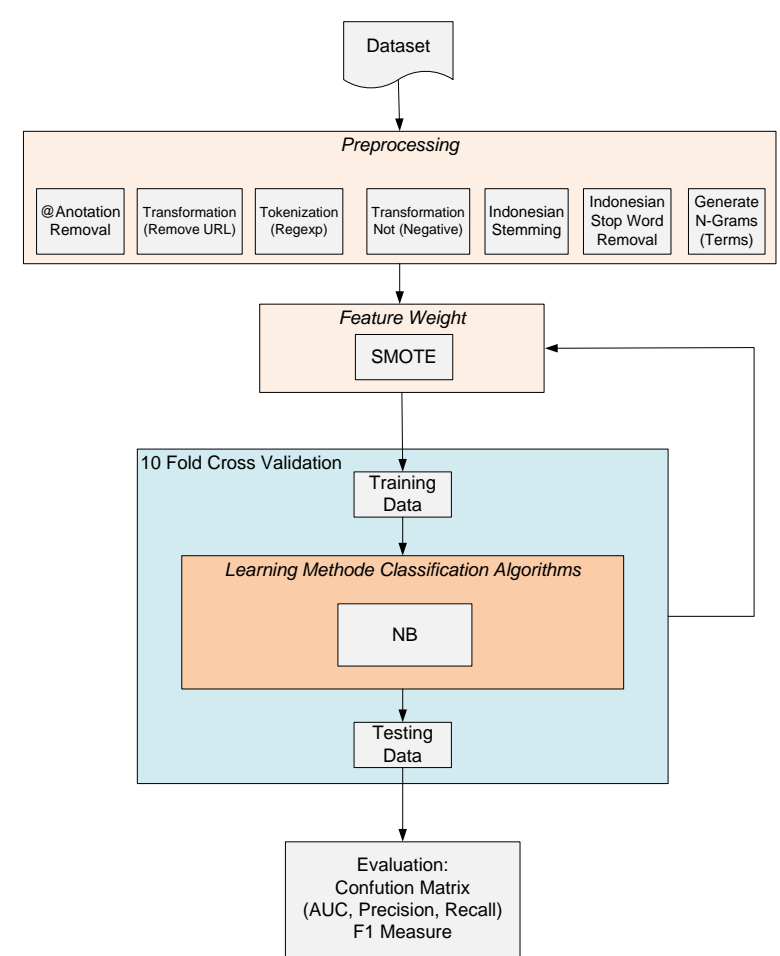

Source: (Amsury, Ruhyana, Saputra, \& Sulistyowati, 2020)

Figure 1. Research methods below:

An example of a dataset is shown in table 1

Table 1. Customer complaint dataset

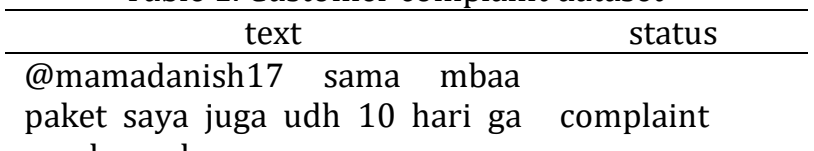

gerak gerak

Barang saya masih disorting center. Kapan dikirim nya udah 10 hari. 150940218361518 no

complaint resinya

@adhyepatie87 tanpa customer @jne_id tidak akan ada di muka bumi ini. Tolong ya dengarkan keluh kesah kami. Setiap pekerjaan pasti ada resikonya. Dan saat inilah JNE harus menghadapi itu.

@sharfinanovi dari batam memang pengiriman agak lama dikarenakan dia masuk ke bea notcomplaint cukai dulu

@yanisutri660 expedisi mana pun pasti mengalami hal yg sama @udilnd123 biasa mas apa lagi ini akhir tahun ya pasti ada overload nya,semoga barang mas notcomplaint cepat sampai dgn selamat

Source: (Amsury et al., 2020)
The preprocessing stage carries out the text processing process starting from @anotation removal, transformation removes URL, tokenization, not negative transformation, Indonesian stemming, Indonesian stopword removal, and n-gram by term. The SMOTE technique is used to balance the unbalanced data between the complaint label and the not complaint label, followed by modeling using the naïve Bayes algorithm and implementing the data using the rapid-miner application with the confusion matrix as a means of measuring the performance of the classification algorithm.

\section{RESULTS AND DISCUSSION}

Business understanding of what will be discussed in this study is to understand the processes that will be produced for both organizations and individuals. What will be discussed in this study as understanding the organization to improve organizational quality, at this stage the researcher makes a question what is the purpose of this text mining research? namely to improve services on freight forwarding services in response to customer complaints.

The classification model approach to Instagram comments that will be used by the Naïve Bayes algorithm adds SMOTE techniques and NGram feature extraction (Ruhyana \& Rosiyadi, 2019) to improve the accuracy of the classification method used in the Instagram comment text dataset.

The second stage of CRISP-DM is that understanding data is needed to have an understanding of the data that will be used in the research process. The data used for this research experiment was collected through Instagram comment data from Instagram social media regarding customer complaints on one of the goods delivery service accounts using the Python API Instagram using the Python language on Github created by Levasha by only taking local text data. Instagram comments, then local data is labeled using the Crowdsourced labeling method is a data labeling method that involves the participation of the general public, of course for datasets that do not require special skills to label them or learn from participants in labeling. The results of selecting datasets are made in Microsoft Excel to be processed in data testing.

Data preparation is the data preparation stage for the text mining process, taking the data from the Instagram comment of the delivery service account, namely @jne_id from September 2018 to November 2018. The data structure taken from Instagram consists of several columns, 
namely the account name and the comment text used in The limitation of this problem is only the comment text and adding a new field, namely the status, to be used as a class or label. The content of Instagram has a lot of information related to customer complaints of Instagram social media users, which is shown to the Instagram account @jd_id delivery service. Before calculating using the proposed model, the data is cleaned so that the data is by the calculation method by eliminating noise and inconsistent data, the data preparation stages are as follows:

@Anotation removal is text parsed based on white space. In this process, all the annotations contained in Instagram comments will be removed, and turn all capital letters into lowercase letters. The results of text processing areas in table 2 below:

Table 2. Preprocessing @Anotation Removal Process

\begin{tabular}{|c|c|}
\hline $\begin{array}{l}\text { Text before processing } \\
\text { @Anotation Removal }\end{array}$ & $\begin{array}{l}\text { Text after processing } \\
@ \text { Anotation Removal }\end{array}$ \\
\hline $\begin{array}{l}\text { @ichal_firmansyah08 } \\
\text { complain kmn? Saya } \\
\text { sdh datengin ke } \\
\text { gudangnya langsung, } \\
\text { saya coba email, dan } \\
\text { balasannya barang } \\
\text { sudah diterima oleh } \\
\text { saya. Jelas2 sy tidak } \\
\text { terima sama skali. } \\
\text { https://www.jne.co.id/i } \\
\text { d/tracking/trace }\end{array}$ & $\begin{array}{l}\text { complain kmn? Saya } \\
\text { sdh datengin ke } \\
\text { gudangnya langsung, } \\
\text { saya coba email, dan } \\
\text { balasannya barang } \\
\text { sudah diterima oleh } \\
\text { saya. Jelas2 sy tidak } \\
\text { terima sama skali. } \\
\text { https://www.jne.co.id/i } \\
\text { d/tracking/trace }\end{array}$ \\
\hline
\end{tabular}

Source: (Amsury et al., 2020)

Transformation Remove URL, the result of @anotation removal will continue to the Transformation Remove URL process, in this process the link or URL contained in Instagram comments will be removed. The results of text processing areas in table 3 below:

Tabel 3. Preprocessing Transformation Remove URL Process

\begin{tabular}{ll}
\hline $\begin{array}{c}\text { Text before processing } \\
\text { Tokenize Remove }\end{array}$ & $\begin{array}{c}\text { Text after processing } \\
\text { Tokenize Remove } \\
\text { HTTP/HTTPS }\end{array}$ \\
\hline complain kmn? Saya sdh & $\begin{array}{c}\text { complain kmn? Saya sdh } \\
\text { datengin ke gudangnya } \\
\text { datengin ke gudangnya }\end{array}$ \\
langsung, saya coba email, & $\begin{array}{l}\text { langsung, saya coba email, } \\
\text { dan balasannya barang } \\
\text { dan balasannya barang }\end{array}$ \\
sudah diterima oleh saya. & sudah diterima oleh saya. \\
Jelas2 sy tidak terima sama & $\begin{array}{l}\text { Jelas2 sy tidak terima sama } \\
\text { skali. }\end{array}$ \\
hkali. & \\
https://www.jne.co.id/id/ & \\
tracking/trace &
\end{tabular}

Source: (Amsury et al., 2020)
Tokenization (Regexp), the result of Transformation Remove URL is continued by the Tokenization process (Regexp), where all the words in each document are collected and punctuated and removed if there are symbols, special characters, or anything that is not a letter. The results of text processing areas in table 4 below:

Table 4. Preprocessing Tokenization (Regexp) Process

\begin{tabular}{ll}
\hline $\begin{array}{c}\text { Text before processing } \\
\text { Tokenization regexp }\end{array}$ & $\begin{array}{l}\text { Text after processing } \\
\text { Tokenization regexp }\end{array}$ \\
\hline complain kmn? Saya sdh & $\begin{array}{l}\text { complain kmn Saya sdh } \\
\text { datengin ke gudangnya } \\
\text { datengin ke gudangnya }\end{array}$ \\
langsung, saya coba email, & $\begin{array}{l}\text { langsung saya coba email } \\
\text { dan balasannya barang } \\
\text { dan balasannya barang }\end{array}$ \\
sudah diterima oleh saya. & $\begin{array}{l}\text { sudah diterima oleh saya } \\
\text { Jelas2 sy tidak terima }\end{array}$ \\
sama skali. & $\begin{array}{l}\text { Jelas sy tidak terima sama } \\
\text { skali }\end{array}$ \\
\hline Source: (Amsury et al., 2020)
\end{tabular}

Transformation Not Negative, From the results of the Indonesian Slank Normalization, the next is a not negative transformation process. In this process, words that have a negative value will be converted into non-negative sentences. The results of text processing are as in table 5 below:

Table 5. Preprocessing Transformation Not Negative Process

\begin{tabular}{cl}
\hline $\begin{array}{c}\text { Text before processing } \\
\text { transformation not } \\
\text { negative }\end{array}$ & $\begin{array}{c}\text { Text after processing } \\
\text { transformation not } \\
\text { negative }\end{array}$ \\
\hline complain kmn Saya sdh & $\begin{array}{l}\text { complain kmn Saya sdh } \\
\text { datengin ke gudangnya }\end{array}$ \\
langsung saya coba email & $\begin{array}{l}\text { langsung saya gudangnya } \\
\text { dan balasannya barang }\end{array}$ \\
dan balasannya barang & $\begin{array}{l}\text { dan bay } \\
\text { sudah diterima oleh saya } \\
\text { sudah diterima oleh saya }\end{array}$ \\
Jelas sy tidak terima sama & $\begin{array}{l}\text { Jelas sy tidakterima sama } \\
\text { skali }\end{array}$ \\
\hline
\end{tabular}

Source: (Amsury et al., 2020)

Indonesian Stemming, the result of the not negative transformation will be carried out by a stemming process, namely changing words that have affixes into basic words using Indonesian stemming for Instagram comments. The results of text processing are as in table 6 below:

Table 6. Preprocessing Indonesia Stemming Process

\begin{tabular}{|c|c|}
\hline $\begin{array}{l}\text { Text before processing } \\
\text { Indonesia stemming }\end{array}$ & $\begin{array}{l}\text { Text after processing } \\
\text { Indonesia stemming }\end{array}$ \\
\hline $\begin{array}{l}\text { complain kmn Saya sdh } \\
\text { datengin ke gudangnya } \\
\text { langsung saya coba email } \\
\text { dan balasannya barang } \\
\text { sudah diterima oleh saya } \\
\text { Jelas sy tidak_terima sama } \\
\text { skali }\end{array}$ & $\begin{array}{l}\text { complain kmn Saya sdh } \\
\text { dateng ke gudang } \\
\text { langsung saya coba email } \\
\text { dan balas barang sudah } \\
\text { terima oleh saya Jelas sy } \\
\text { tidak_terima sama skali }\end{array}$ \\
\hline
\end{tabular}


Indonesian Stopword Removal, the results of Indonesian stemming will be continued to the Indonesian stopword removal process, in this process irrelevant words will be deleted, such as words but, for, with, which have no separate meaning if separated by other words and not related to adjectives related to sentiment. The results of text processing areas in table 7 below:

Table 7. Preprocessing Indonesian Stopword Removal Process

\begin{tabular}{|c|c|}
\hline $\begin{array}{l}\text { Text before processing } \\
\text { stopword removal }\end{array}$ & $\begin{array}{l}\text { Text after processing } \\
\text { stopword removal }\end{array}$ \\
\hline $\begin{array}{l}\text { complain kmn Saya sdh } \\
\text { dateng ke gudang } \\
\text { langsung saya coba } \\
\text { email dan balas barang } \\
\text { sudah terima oleh saya } \\
\text { Jelas sy tidak_terima } \\
\text { sama skali }\end{array}$ & $\begin{array}{lr}\text { complain } & \text { kmn sdh } \\
\text { dateng } & \text { gudang } \\
\text { langsung coba email } & \text { balas barang sudah } \\
\text { terima } & \text { Jelas } \\
\text { tidak_terima sama skali }\end{array}$ \\
\hline
\end{tabular}

Extraction of the N-Gram (Term) Feature, the results of the Indonesian stop-word removal will be continued in the last process, namely Generate $\mathrm{n}$-Gram (Terms) is a set of words given in a paragraph and when calculating n-grams is usually done by moving one word forward, in this stage using the trigram. The results of text processing areas in table 8 below:
Table 8. Preprocessing Ekstraksi Fitur N-Gram

\begin{tabular}{|c|c|}
\hline \multicolumn{2}{|c|}{ Process } \\
\hline $\begin{array}{c}\text { Text before } \\
\text { processing N-Gram }\end{array}$ & $\begin{array}{c}\text { Text after processing } \\
\text { N-Gram }\end{array}$ \\
\hline $\begin{array}{l}\text { complain kmn sdh } \\
\text { dateng gudang } \\
\text { langsung coba email } \\
\text { balas barang sudah } \\
\text { terima Jelas } \\
\text { tidak_terima sama } \\
\text { skali }\end{array}$ & $\begin{array}{l}\text { complain complain_kmn } \\
\text { complain_kmn_sdh kmn } \\
\text { kmn_sdh } \\
\text { kmn_sdh_dateng sdh } \\
\text { sdh_dateng } \\
\text { sdh_dateng_gudang } \\
\text { dateng dateng_gudang } \\
\text { dateng_gudang_langsung } \\
\text { gudang gudang_langsung } \\
\text { gudang_langsung_coba } \\
\text { langsung langsung_coba } \\
\text { langsung_coba_email } \\
\text { coba coba_email } \\
\text { coba_email_balas email } \\
\text { email_balas } \\
\text { email_balas_barang balas } \\
\text { balas_barang } \\
\text { balas_barang_sudah } \\
\text { barang barang_sudah } \\
\text { barang_sudah_terima } \\
\text { sudah sudah_terima } \\
\text { sudah_terima_jelas } \\
\text { terima terima_jelas } \\
\text { terima_jelas_tidak_terima } \\
\text { jelas jelas_tidak_terima } \\
\text { jelas_tidak_terima_sama } \\
\text { tidak_terima tidak_terima _sama } \\
\text { tidak_terima_sama_sekali } \\
\text { sama sama_sekali skali }\end{array}$ \\
\hline
\end{tabular}

Source: (Amsury et al., 2020)

Based on Figure 2 is a confusion matrix model in a rapid-miner application using the Naïve Bayes algorithm.

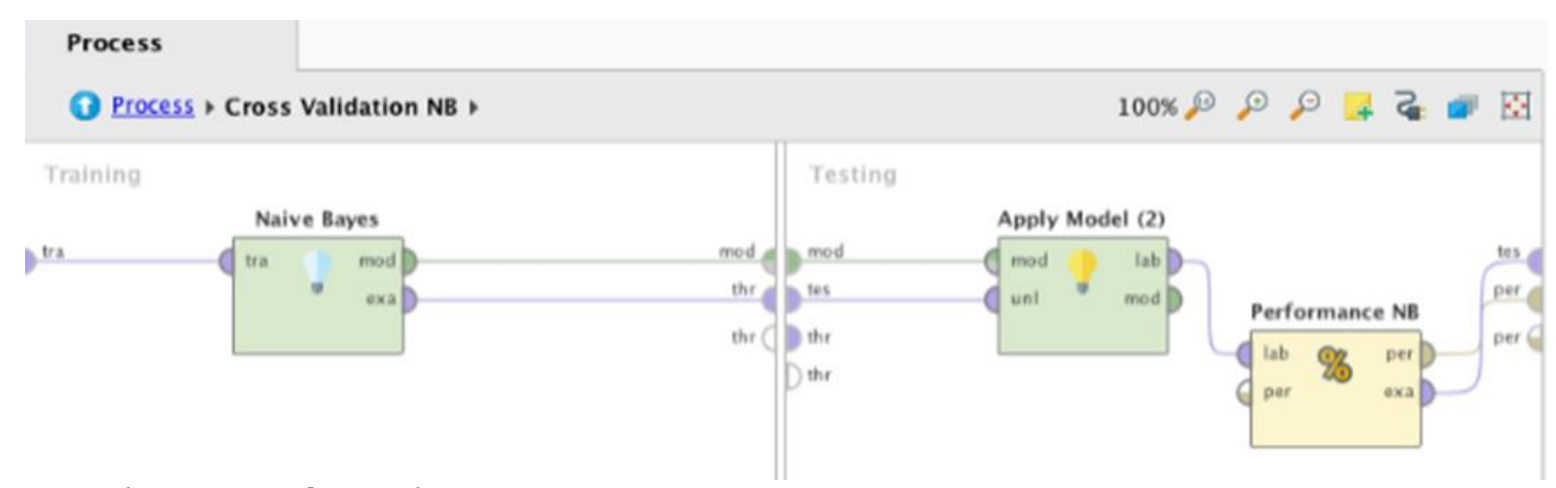

Source: (Amsury et al., 2020)

Figure 2. Process Models CRISP-DM 


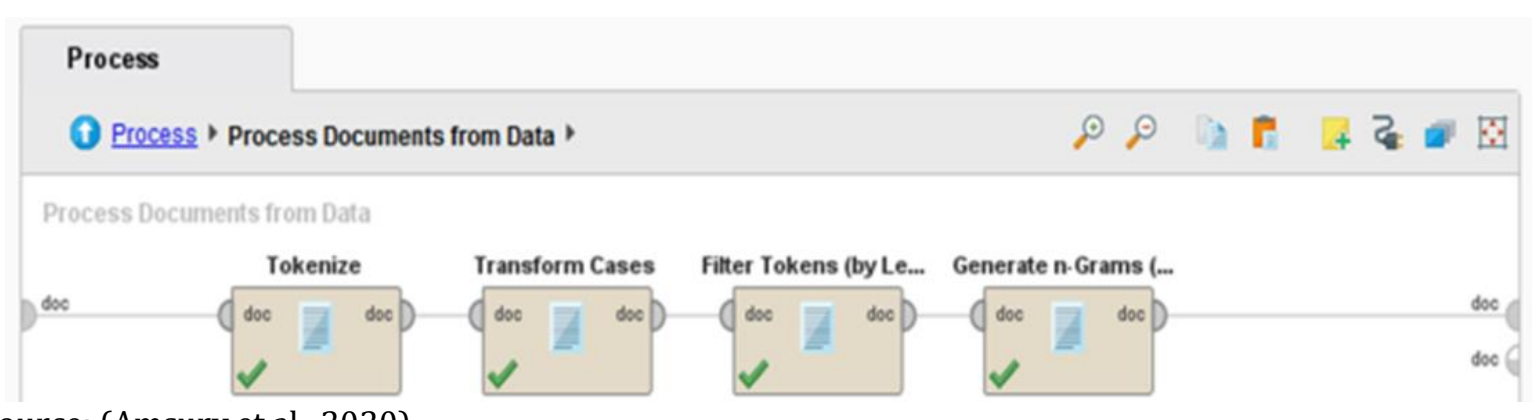

Source: (Amsury et al., 2020)

Figure 3. Stages of Process Document From Data

Based on Figure 3, it is a documented process carried out in the Rapid-miner application by adding n-gram by terms. The results of testing Indonesian Instagram comment data with 776 records using the Naïve Bayes + SMOTE and Naïve Bayes + SMOTE + N-Gram methods can be seen in the table.

Table 9. Confusion Matrix Method Naïve Bayes + SMOTE

\begin{tabular}{cccl}
\hline Accuracy: 88,54\%+/-2,38\% & \\
\hline & $\begin{array}{l}\text { True } \\
\text { Complai } \\
\text { nt }\end{array}$ & $\begin{array}{l}\text { True } \\
\text { NotComplai } \\
\text { nt }\end{array}$ & $\begin{array}{l}\text { Class } \\
\text { Precisio } \\
\text { n }\end{array}$ \\
\hline $\begin{array}{c}\text { Pred. } \\
\text { Complaint }\end{array}$ & 461 & 34 & $93,13 \%$ \\
\hline $\begin{array}{c}\text { Pred. } \\
\text { NotComplai } \\
\text { nt }\end{array}$ & 93 & 520 & $84,83 \%$ \\
\hline Class Recall & $83,21 \%$ & $93,86 \%$ & \\
\hline
\end{tabular}

Source: (Amsury et al., 2020)

Based on table 9, the accuracy results for the naïve Bayes method with the SMOTE technique are $88.54 \%$, with the precision prediction complaint class of $93.13 \%$ and the precision prediction not complaint class of $84.83 \%$. True complaint recall class was $83.21 \%$ and true not complaint recall class was $93.86 \%$.

Table 10. Confusion Matrix Metode Naïve Bayes + SMOTE + N-Gram

\begin{tabular}{cll}
\hline Accuracy: $89,98 \%+/-2,09 \%$ & \\
\hline True & True & Class \\
Complai & NotComplai & Precisio \\
nt & nt & n \\
\hline
\end{tabular}

\begin{tabular}{cccc} 
& nt & nt & n \\
\hline $\begin{array}{c}\text { Pred. } \\
\text { Complaint }\end{array}$ & 466 & 23 & $95,30 \%$ \\
\hline $\begin{array}{c}\text { Pred. } \\
\text { NotComplai } \\
\text { nt }\end{array}$ & 88 & 531 & $85.78 \%$ \\
\hline Class Recall & $84.12 \%$ & $95,86 \%$ &
\end{tabular}

Source: (Amsury et al., 2020)
Based on table 10, the accuracy results for the naïve Bayes method with the SMOTE technique and the N-Gram feature is $89.98 \%$, with the precision prediction complaint class of $95.30 \%$ and the precision prediction not complaint class of $85.78 \%$. True complaint recall class was $84.12 \%$ and true not complaint recall class was $95.86 \%$.

\begin{tabular}{ccc}
\multicolumn{3}{c}{ Table 11. Evaluation F-Measure } \\
\hline & NB + SMOTE & $\begin{array}{c}\text { NB +SMOTE + N- } \\
\text { Gram }\end{array}$ \\
\hline $\begin{array}{c}\text { F- } \\
\text { Measure }\end{array}$ & $89.14 \%$ & $90.56 \%$ \\
\hline
\end{tabular}

Source: (Amsury Fachri, et al., 2020)

Based on table 11 , the results of the $\mathrm{F}$ Measure evaluation for the naïve Bayes algorithm with the SMOTE technique are $89.14 \%$ while the naïve Bayes algorithm with the SMOTE technique and the N-Gram feature is $90.56 \%$, seen from the testing process of the Naïve Bayes algorithm model using the technique. SMOTE and Naïve Bayes using the SMOTE technique and the N-Gram feature, the highest model test results of all algorithm test results are SMOTE-based Naïve Bayes and the $\mathrm{N}$ Gram feature. Therefore the weight to be used in application modeling is based on the test results of the Naïve Bayes algorithm based on the SMOTE technique and the N-Gram feature.

\section{CONCLUSION}

Based on the results of the research that has been carried out, a model has been successfully built to classify customer complaints on delivery services on Instagram accounts, it can be concluded that the naïve Bayes classification algorithm uses the SMOTE technique which processes Instagram comment data regarding 776 records of customer complaints of freight forwarding services. an accuracy rate of $88.54 \%$ while the results of the naïve Bayes classification using the SMOTE technique with the N-Gram feature found that an accuracy rate of $89.98 \%$ was proven by using the $\mathrm{N}$-Gram feature to increase the accuracy rate by 
$1.44 \%$ compared to without using the N-Gram feature.

The suggestions that can be conveyed by data processing needs are to use different classification algorithms such as Decision Tree, Random Forest, k-NN so that different research can be carried out from the existing ones. Using other feature selection methods such as Chi-Square, Gini Index, Mutual Information Part of Speech (POS), etc. so that the results can be compared. Enrich the dataset used so that research can be more specific and accurate.

\section{REFERENCE}

Amsury, F., Ruhyana, N., Saputra, I., \& Sulistyowati, D. N. (2020). Laporan Akhir Penelitian Mandiri: Klasifikasi Keluhan Pelanggan Pada Komentar Instagram Menggunakan Algortima Naïve Bayes Dengan Ekstarksi Fitur N-Gram. Jakarta.

APJII. (2019). Buletin APJII Edisi-40 - Mei 2019: Survei APJII yang Ditunggu-tunggu,Penetrasi Internet Indonesia 2018. Retrieved from apjii.or.id website: https://apjii.or.id/content/read/104/418/B ULETIN-APJII-EDISI-40---Mei-2019

Dellia, P., \& Tjahyanto, A. (2017). Tax Complaints Classification on Twitter Using Text Mining. IPTEK Journal of Science, 2(1), 11-15. https://doi.org/10.12962/j23378530.v2i1.a2 254

Dewi, R. N. (2018). Model Text Mining Untuk Identifikasi Keluhan Pelanggan Produk Perusahaan Perangkat Lunak (Universitas Islam Indonesia). Universitas Islam Indonesia. Retrieved from https://dspace.uii.ac.id/bitstream/handle/12 3456789/10239/Tesis Rona Neysa Dewi 12917229.pdf?sequence $=2 \&$ isAllowed $=y$

Hartini, S. (2016). Efektifitas Endorsment pada Media Sosial Instagram pada Produk Skin Care. Bina Insani ICT Journal, 3(1), 43-50. Retrieved from http://www.ejournalbinainsani.ac.id/index.php/BIICT/article/vie $\mathrm{w} / 794$

Indriyani, S., \& Mardiana, S. (2016). Pengaruh Penanganan Keluhan (Complaint Handling) Terhadap Kepercayaan Dan Komitmen Mahasiswa Pada Perguruan Tinggi Swasta Di Bandar Lampung. Jurnal Bisnis Darmajaya, 2(1), 1-13. Retrieved from https://journal.darmajaya.ac.id/index.php/Ju
rnalBisnis/article/view/615

Indriyani, Susi. (2014). FAKTOR EMPATI DALAM PENANGANAN KELUHAN TERHADAP KEPERCAYAAN DAN KOMITMEN MAHASISWA DI STIE MITRA LAMPUNG. Seminar Bisnis \& Teknologi 2014 IBI Darmajaya, 1-15. Bandar Lampung: Institut Informatika Dan Bisnis Darmajaya. Retrieved from

https://jurnal.darmajaya.ac.id/index.php/se mbistek/article/view/199

Laksana, J., \& Purwarianti, A. (2015). Indonesian Twitter text authority classification for government in Bandung. Proceedings - 2014 International Conference on Advanced Informatics: Concept, Theory and Application, ICAICTA 2014, 129-134. https://doi.org/10.1109/ICAICTA.2014.7005 928

Mayasari, I. Y., \& Indriyani, R. (2016). Analisis Strategi Bersaing pada PT.Citra Surya Pacific. AGORA, 4(2), 188-196. Retrieved from http://publication.petra.ac.id/index.php/ma najemen-bisnis/article/view/4803

Putri, R. L. (2016). Peningkatan Kualitas Produk Melalui Penerapan Prosedur dan Sistem Produksi : Studi Pada UD Wijaya Kusuma Kota Blitar. Jurnal Wahana Riset Akuntansi, 4(2), 813-828. Retrieved from http://ejournal.unp.ac.id/index.php/wra/arti cle/view/7223/

Ruhyana, N., \& Rosiyadi, D. (2019). Klasifikasi Komentar Instagram Untuk Identifikasi Keluhan Pelanggan Jasa Pengiriman Barang Dengan Teknik Smote. Faktor Exacta, 12(4), 280-290.

https://doi.org/10.30998/faktorexacta.v12i4 .4981

Sabirin, \& Setiawati, C. I. (2017). The driving factors of Instagram utilization for marketing efforts in promoting the student-owned online store. Proceedings - 2016 International Seminar on Application of Technology for Information and Communication, ISEMANTIC 2016, 64-69. https://doi.org/10.1109/ISEMANTIC.2016.7 873811

Setiawan, R. A., \& Setyohadi, D. B. (2017). Analisis Komunikasi Sosial Media Twitter sebagai Saluran Layanan Pelanggan Provider Internet dan Seluler di Indonesia. Journal of 
Information Systems Engineering and Business Intelligence, $3(1)$, https://doi.org/10.20473/jisebi.3.1.16-25
Widagdo, P. B. (2016). Perkembangan Electronic Commerce ( $E$ - Commerce) di Indonesia. Yogjakarta.

Sieber, J. E. (2008). Data Mining: Knowledge Discovery for Human Research Ethics. Journal of Empirical Research on Human Research Ethics, 3(3), 1-2. https://doi.org/10.1525/jer.2008.3.3.1 